\title{
THE RETARDATION OF ERYTHROCYTE SEDIMENTATION IN CONGESTIVE HEART FAILURE
}

\author{
BY \\ L. M. SANGHVI AND B. M. BOHRA \\ From the Department of Cardiology, Sawai Man Singh Hospital and Medical College, Jaipur, India \\ Received August 7, 1961
}

While it is generally believed that congestive heart failure retards erythrocyte sedimentation (E.S.R.) the data of McGinnis et al. (1953) indicated that the E.S.R. tends to be elevated in both acute and chronic congestive failure. From a study of E.S.R. in 190 patients with cardiac failure of varied aetiology, Sanghvi (1960) concluded that heart failure has a retarding influence on the E.S.R. and tends to bring nearer to the normal the E.S.R. in diseases known to be associated with abnormally elevated values; he also found that elevation of the E.S.R. values after compensation is due to removal of this retarding influence. The cause of retardation of the E.S.R. during failure or of elevation after compensation is not yet known, and publications on the subject are few. McGinnis et al. (1953) suggested that absorption of products of tissue necrosis as a result of passive congestion may play a part in the increase of E.S.R. in the period immediately after compensation. Parry (1961) in a study of factors which may influence the E.S.R. in heart failure found no correlation between the changes in the E.S.R. and in the plasma fibrinogen and serum protein fractions. The purpose of this paper is to report a study, during heart failure and after establishment of compensation, of E.S.R. and various factors known to influence the E.S.R. in 35 patients.

\section{Material AND Methods}

Thirty-five patients admitted to the S.M.S. Hospital for treatment of congestive heart failure due to coronary, rheumatic, and emphysema heart disease, and hypertensive heart disease with renal involvement, were selected for this study (Table I). The E.S.R. was determined by the method of Westergren on admission and at intervals of 7 to 10 days until after the relief of heart failure; 1.6 c.c. of venous blood was drawn in a syringe containing 0.4 c.c. of 3.8 per cent sodium citrate solution. Sedimentation tubes were kept in an incubator at $37^{\circ} \mathrm{C}$. and readings were noted at the end of one hour. For the purpose of this study, a reading of $15 \mathrm{~mm}$. or more at the end of one hour was considered abnormally elevated and pathological, and an increase of $5 \mathrm{~mm}$. or more from initial value after compensation was considered a significant elevation. The group of cases in which the E.S.R. values rose significantly after compensation has been designated as SR + group, and in which the values did not change significantly or decreased has been designated as SR - group.

Venous pressure was determined by direct method, and arm to lung and arm to tongue circulation times by ether and magnesium sulphate methods, respectively. Other laboratory data were obtained in each patient, on admission and after compensation, and in 20 normal healthy individuals to serve as normal controls. The data included determination of total serum proteins by the copper sulphate specific gravity method of Moore and Van Slyke (1930), the normal control range being 6.0 to $8 \cdot 1 \mathrm{gm}$. per cent; plasma fibrinogen by Quick's (1942) method, normal range being 190 to $380 \mathrm{mg}$. per cent; total and esterified serum cholesterol by the lumetron photoelectric colorimeter, 
TABLE I

incidence of Normal and AbNormal E.S.R. on Admission and of Significant Elevation after Compensation

\begin{tabular}{|c|c|c|c|c|c|c|c|c|c|}
\hline \multirow{3}{*}{\multicolumn{2}{|c|}{ Heart disease }} & & \multirow{3}{*}{$\begin{array}{l}\text { Total } \\
\text { cases }\end{array}$} & \multirow{3}{*}{$\begin{array}{l}\text { No. with } \\
\text { elevation }\end{array}$} & \multicolumn{3}{|c|}{ Normal E.S.R. on admission } & \multicolumn{2}{|c|}{$\begin{array}{c}\text { Abnormal E.S.R. on } \\
\text { admission }\end{array}$} \\
\hline & & & & & \multirow[b]{2}{*}{$\begin{array}{l}\text { Total } \\
\text { cases }\end{array}$} & \multicolumn{2}{|c|}{$\begin{array}{l}\text { No. with elevation } \\
\text { after compensation }\end{array}$} & \multirow[b]{2}{*}{$\begin{array}{l}\text { Total } \\
\text { cases }\end{array}$} & \multirow{2}{*}{$\begin{array}{l}\text { No. with further } \\
\text { elevation after } \\
\text { compensation }\end{array}$} \\
\hline & & & & & & Total & $\begin{array}{l}\text { Abnormal } \\
\text { elevation }\end{array}$ & & \\
\hline $\begin{array}{l}\text { Rheumatic } \\
\text { Emphysema } \\
\text { Hypertensive } \\
\text { Coronary }\end{array}$ & $\begin{array}{l}\ldots \\
\ldots \\
\ldots \\
\ldots\end{array}$ & $\begin{array}{l}. \\
. \\
.\end{array}$ & $\begin{array}{r}7 \\
13 \\
5 \\
10\end{array}$ & $\begin{array}{r}4 \\
11 \\
3 \\
10\end{array}$ & $\begin{array}{r}3 \\
10 \\
0 \\
4\end{array}$ & $\begin{array}{l}2 \\
8 \\
0 \\
4\end{array}$ & $\begin{array}{l}2 \\
6 \\
0 \\
2\end{array}$ & $\begin{array}{l}4 \\
3 \\
5 \\
6\end{array}$ & $\begin{array}{l}2 \\
3 \\
3 \\
6\end{array}$ \\
\hline$\overline{\text { Total }}$ & $\cdots$ & .. & 35 & 28 & 17 & 14 & 10 & 18 & 14 \\
\hline
\end{tabular}

normal range being 110 to $230 \mathrm{mg}$. for total cholesterol and 50 to 70 per cent of the total for esterified cholesterol; total serum bilirubin by the method of Haslewood and King (1937), the normal range being 0.4 to $1.2 \mathrm{mg}$. per cent; thymol turbidity and flocculation tests by McLagan's (1947) method, normal being up to 5 units and one plus, respectively; carbon dioxide combining power of plasma by the volumetric method of Van Slyke and Cullen (1917), normal range being 25 to $30 \mathrm{mEq} . / 1$.; and packed cell volume of blood by Wintrobe's (1956) method, normal range being 38 to 45 c.c. Serum protein fractions were determined by the paper electrophoretic method of Flynn and Mayo (1951); their range and mean values in normal controls are given in Table II. After compensation either a decrease or an increase of total serum protein and protein-fractions by 10 per cent or more of the initial value was considered a significant alteration. An increase of more than $25 \mathrm{mg}$. in the fibrinogen level after compensation was considered a significant elevation.

\section{RESULTS}

The incidence of normal and abnormally elevated E.S.R. values on admission and after compensation and of significant rise of E.S.R. from initial values after compensation is given in Table I. On admission the E.S.R. values were normal in 17 and abnormal in 18 patients, and after compensation, they were normal in 7 and abnormal in 28. After compensation the values showed no significant change in 5, a decrease in 2 (SR - group), and a significant increase in 28 cases (SR + group). Of 17 patients with normal initial values, in 10 these became abnormal and in 4 there was elevation with values still remaining normal. Of 18 cases with abnormal initial values there was further elevation in 14. In 7 instances the E.S.R. remained normal initially as well as after compensation.

The venous pressure varied between 8 and $22 \mathrm{~cm}$. of normal saline and was raised in 32 patients, being more than $18 \mathrm{~cm}$. in 15 . Arm to lung circulation time varied between 7 and 14 seconds and was prolonged in 28 cases, being more than 10 seconds in 12. Arm to tongue circulation time varied between 14 and 25 seconds and was prolonged in 33 instances, being more than 20 seconds in 9 .

Packed cell volume of blood varied between 38 and 62 per cent with an average of 45.5 per cent on admission, and 38 and 58 per cent with an average of 45 per cent after compensation. In two cases of chronic pulmonary heart disease there was polycythæmia. The carbon dioxide combining power of plasma varied between 23 and $32.5 \mathrm{mEq} / 1$. with an average of 27 on admission, and 24 and $29 \mathrm{mEq}$./1. with an average of 27.2 after compensation. There was no significant difference between the values on admission and after compensation.

Serum bilirubin values on admission varied between 0.4 to $3.0 \mathrm{mg}$. per cent, and were increased in 20 cases, being more than $2.5 \mathrm{mg}$. in 4 of them. In all the patients the values returned to normal after compensation. These results showed no relation to normal or abnormal values of E.S.R. on admission; of 20 cases with raised levels and 15 cases with normal levels, 10 and 7 cases, respectively, 
TABLE II

Blood Proteins: Control Values, Mean Values and Incidence of Abnormal Values on Admission and after Compensation, and InCidence of Significant Alteration after Compensation

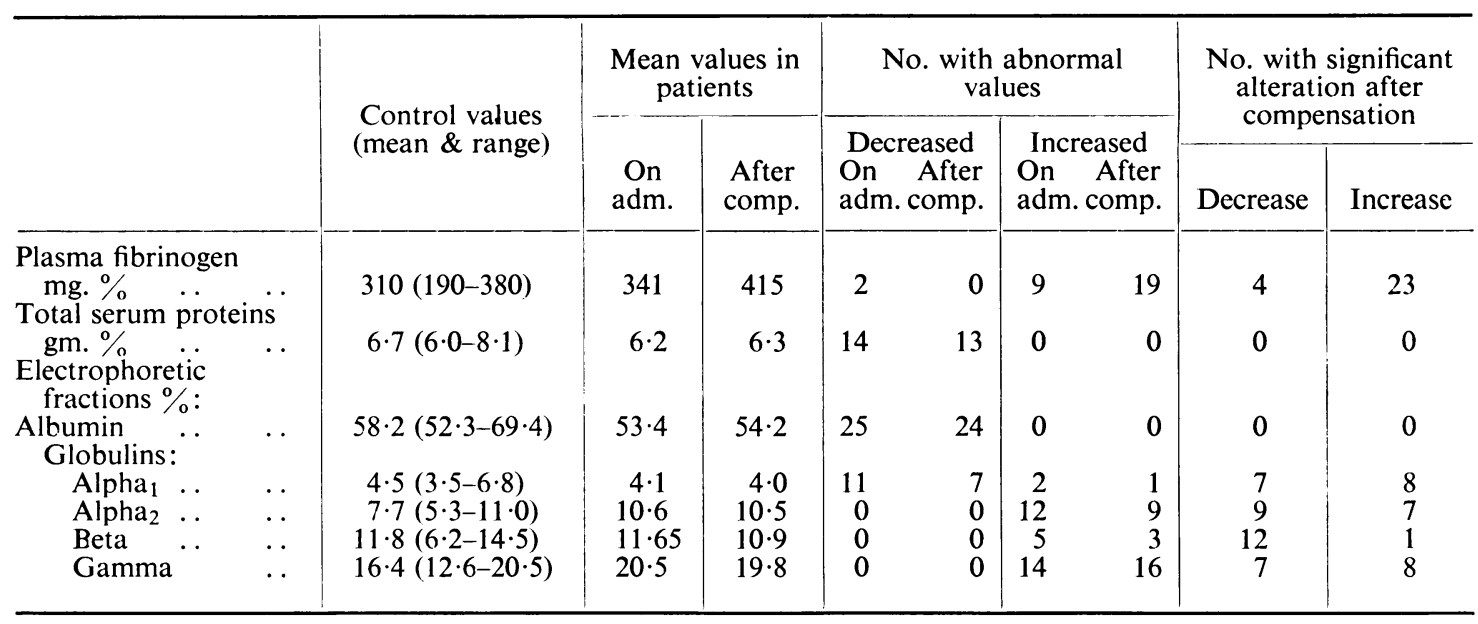

had normal E.S.R. Bilirubin concentration was not found to show any constant relation to venous pressure or circulation times. Total serum cholesterol values were decreased in 6 patients, in all of whom they returned to normal after compensation. Esterified cholesterol values were decreased in 26 cases on admission and in 2 after compensation. Thymol turbidity and flocculation tests of liver function were abnormal in 13 patients on admission and in 5 after compensation; in 11 of these 13 cases the serum bilirubin was abnormally elevated. The incidence of abnormality of these tests on admission in SR + and SR - groups is given in Table III.

Mean values of total serum proteins and electrophoretic protein fractions and incidence of abnormal values on admission and after compensation are given in Table II. On admission the total serum proteins varied between 5.0 and $8.1 \mathrm{gm}$. per cent with an average of $6.2 \mathrm{gm}$., and were decreased and less than $6 \mathrm{gm}$. in 14 instances. The serum albumin fraction varied between 48 and 60.5 per cent with an average of 53.4 per cent, and was less than $3.5 \mathrm{gm}$. per cent in 25 cases. Alpha globulins were decreased in 11 patients. Alpha $_{2}$ globulins were increased in 12 cases, beta globulins in 5, and gamma globulins in 14 . Total globulins were increased and more than $3 \cdot 1 \mathrm{gm}$. per cent in 7 cases. One or more globulin fractions were abnormal in a total of 27 patients. The incidence of alterations in proteins after compensation is given in Table II. There was no significant difference in the incidence of abnormal values at the time of admission and after compensation. After compensation total proteins increased in 15 and decreased in 6 cases, and albumin increased in 27 and

TABLE III

Incidence of Abnormal Liver Function Tests on Admission IN SR + AND SR - GROUPS

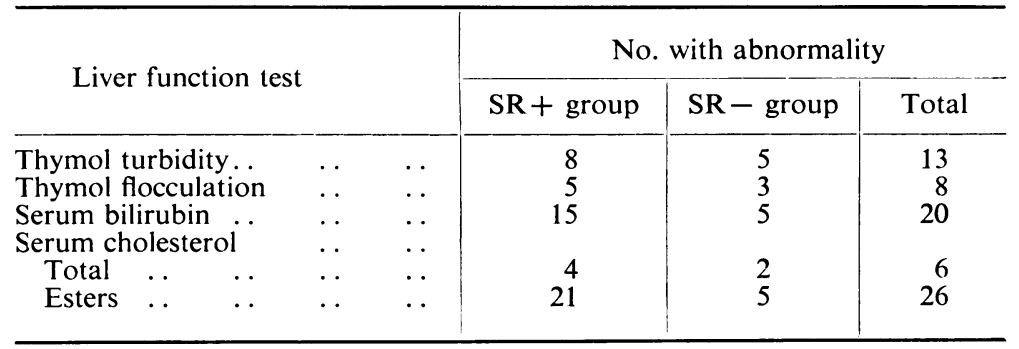


decreased in 5. In no instance, however, did these values show significant alteration and total protein and albumin remained decreased in 13 and 24 cases, respectively. The values of the globulin fractions increased significantly in some cases and decreased in others, but again, there was no significant difference in the incidence of significant alteration of the values, except in the case of beta globulin which decreased in 12 cases but increased in only one. Total globulins remained elevated in all the 7 cases and gamma globulins in 13. Changes in the values of serum protein fractions showed no relationship to changes in E.S.R. values.

Plasma fibrinogen values on admission varied between 160 and $705 \mathrm{mg}$. per cent with an average of $341 \mathrm{mg}$.; they were normal in 24 patients, decreased in 2, and abnormally elevated in 9 . After compensation the values varied between 199 and $615 \mathrm{mg}$. with an average of $415 \mathrm{mg}$.; they were normal in 16 and abnormally elevated in 19 cases (Table IV). After compensation the values

TABLE IV

Fibrinogen LeVels and Their Relation to Normal or Abnormal E.S.R. ON Admission and AFTER COMPENSATION

\begin{tabular}{|c|c|c|c|c|c|c|c|c|}
\hline & & & & & & nission & After & pensation \\
\hline Pla & na $f$ & nog & $\mathrm{mg}$. & & & & & No. with \\
\hline $\begin{array}{r}<190 \\
190-380 \\
>380\end{array}$ & $\begin{array}{l}\ddot{ } \\
\cdots \\
\cdots\end{array}$ & $\begin{array}{l}\ddot{*} \\
\ddot{*}\end{array}$ & $\begin{array}{l}\cdots \\
\cdots \\
\cdots\end{array}$ & $\begin{array}{l}\cdots \\
\cdots \\
\cdots\end{array}$ & $\begin{array}{r}2 \\
24 \\
9\end{array}$ & $\begin{array}{l}1 \\
8 \\
9\end{array}$ & $\begin{array}{r}0 \\
16 \\
19\end{array}$ & $\begin{array}{r}0 \\
9 \\
19\end{array}$ \\
\hline Total & .. & .. & & . & 35 & 18 & 35 & 28 \\
\hline
\end{tabular}

increased significantly from initial values in 23 cases, all of them in SR+ group. They decreased in 4 cases, 2 in the SR - group in which the E.S.R. decreased, and 2 in SR + group. They showed no significant change in 8 cases, 3 cases in SR+ and 5 in SR - group. All patients with abnormally elevated values of fibrinogen, on admission as well as after compensation, showed abnormally elevated E.S.R. values. However, 8 cases on admission and 9 after compensation with abnormal E.S.R., showed normal fibrinogen values. The relation between actual increase of E.S.R. values and fibrinogen values from initial values which occurred after compensation is given in Table V. In all

TABLE V

Relation between Actual Rise of E.S.R. AND of Change in Fibrinogen Values after COMPENSATION IN 28 CASES OF SR + GROUP

\begin{tabular}{|c|c|c|c|c|c|c|c|c|}
\hline \multirow{2}{*}{\multicolumn{4}{|c|}{ Rise of E.S.R. mm./hr. }} & \multirow[t]{2}{*}{$\begin{array}{l}\text { Total } \\
\text { cases }\end{array}$} & \multicolumn{3}{|c|}{$\begin{array}{l}\text { No. with elevation of } \\
\text { fibrinogen: } \mathrm{mg} . \%\end{array}$} & \multirow{2}{*}{$\begin{array}{l}\text { No. with } \\
\text { decrease of } \\
\text { fibrinogen }\end{array}$} \\
\hline & & & & & $<25$ & $25-100$ & 100 & \\
\hline $\begin{array}{r}<10 \\
10-15 \\
16-20 \\
>20\end{array}$ & $\begin{array}{l}\ddot{.} \\
\ddot{*} \\
\cdots\end{array}$ & $\begin{array}{l}\ddot{*} \\
\ddot{m} \\
\ddot{m}\end{array}$ & $\begin{array}{l}\ldots \\
\cdots \\
\cdots\end{array}$ & $\begin{array}{r}7 \\
10 \\
7 \\
4\end{array}$ & $\begin{array}{l}2 \\
1 \\
0 \\
0\end{array}$ & $\begin{array}{l}4 \\
3 \\
3 \\
0\end{array}$ & $\begin{array}{l}0 \\
5 \\
4 \\
4\end{array}$ & $\begin{array}{l}1 \\
1 \\
0 \\
0\end{array}$ \\
\hline Total & . & $\cdots$ & . & 28 & 3 & 10 & 13 & 2 \\
\hline
\end{tabular}

the 4 patients with a rise of E.S.R. of more than $20 \mathrm{~mm}$. fibrinogen values increased by more than $140 \mathrm{mg}$., and of 7 cases with rise of E.S.R. of less than $10 \mathrm{~mm}$., in 6 the increase of fibrinogen was less than $60 \mathrm{mg}$. and in 1 the fibrinogen decreased. 


\section{DisCUSSION}

In the present series the E.S.R. values increased significantly after compensation in $28(80 \%)$ patients including 10 in whom the values became abnormally elevated from initial normal values. The heart diseases in patients in our series are known to be often associated with an abnormal E.S.R., and occurrence of normal E.S.R. initially with subsequent elevation to abnormal values strongly suggested that the E.S.R. was retarded by the occurrence of heart failure and that elevation after compensation was due to removal of factors which retarded the E.S.R. during failure.

No correlation could be detected between elevation of E.S.R. values after compensation and changes in the packed cell volume of blood and carbon dioxide combining power of plasma. Abnormal thymol turbidity and flocculation tests in 37 per cent of cases, abnormally elevated serum bilirubin in 57 per cent, and decreased cholesterol esters in 74 per cent of cases on admission, and their return to normal in most of them after compensation indicated impairment of liver function as a result of heart failure (Altshule, 1938; Bernstein et al., 1942; Felder et al., 1950; Evans et al., 1952). These changes also showed no relation to changes in E.S.R. values.

It has been established that in patients with congestive heart failure total serum proteins are often decreased, mostly at the expense of serum albumin, and total globulins are sometimes increased. The electrophoretic pattern of serum protein fractions in congestive heart failure has been studied (Sundermann and Sundermann, 1957; Hammond and Ross, 1960; Parry, 1961). Sundermann and Sundermann (1957) reported decreased total proteins and albumin, and increased alpha globulin $^{2}$ and stated that the latter two changes represent a nonspecific pattern and a common response in many infectious and in metabolic and neoplastic diseases. Hammond and Ross (1960) reported decreased total proteins and albumin, and increased alpha $a_{1}$, gamma and total globulins. These investigators did not correlate these changes to the changes in the E.S.R. Parry (1961) reported that a raised gamma globulin was the commonest globulin fraction change in heart failure and the only constant changes effected by compensation in 8 cases with adequate data were a rise of alpha ${ }_{1}$ globulin from a low to normal values in 5 patients and a persistently raised gamma globulin in 7 . In the present series significant abnormalities of serum protein at the time of admission included decreased total proteins, albumin, and alpha $a_{1}$ globulin, and increased alpha $_{2}$, beta, and gamma globulins. These abnormalities, however, persisted in most of the cases after compensation. The only significant alteration after compensation was decrease of beta globulin from initial values in 12 patients. Other fractions showed either slight decrease or increase but no significant difference in the incidence of the two. The increase in albumin and total proteins after compensation was not significant in any instance despite a loss of 7 to $12 \mathrm{~kg}$. of body weight in 9 cases, and of $5 \mathrm{~kg}$. or more in 25 , and showed no definite relation to the actual weight loss. In almost all the patients in whom they were abnormally decreased, they continued to remain below the normal level. These findings confirm the observations of Herrmann (1946) who also noted small differences in total proteins, albumin, and globulin in cardiac œdematous patients when they became œdema free. Our findings are not in agreement with those of Hammond and Ross (1960) who studied serum proteins in 7 patients before and after treatment of heart failure and noted increase in concentration of albumin in those who quickly lost their œdema. The data in the present series strongly suggest that the changes in proteins are not the result of heart failure but represent a nonspecific pattern probably due to the disease causing heart failure, as suggested by Sundermann and Sundermann (1957).

In the present series abnormally high fibrinogen values were as a rule associated with a raised E.S.R., and normal values of E.S.R. with normal fibrinogen values. There were, however, several patients who had a raised E.S.R. but normal fibrinogen values and thus there was no parallel relationship between the two. It is believed that the abnormal elevation of fibrinogen values in our cases represents a nonspecific response of the organism (Ham and Curtis, 1938) similar to the nonspecific changes in serum proteins in our patients. The most significant finding in this study was a significant increase of fibrinogen values from initial values after establishment of compensation in 23 patients, in all of whom there was also a significant elevation of the E.S.R.; in 13 of them the increase 
was more than $100 \mathrm{mg}$. In 2 cases in which the E.S.R. decreased fibrinogen also decreased significantly. It was also interesting to find that of 7 cases with increase of E.S.R. of less than $10 \mathrm{~mm}$., fibrinogen increased by less than $60 \mathrm{mg}$. in 6 and decreased in one of them; moreover, in all the 4 cases with increase of E.S.R. of more than $20 \mathrm{~mm}$. the fibrinogen increase was more than $140 \mathrm{mg}$. Thus a striking, though not a parallel, correlation was obtained between the changes in the E.S.R. and the fibrinogen values which occurred after compensation.

It has been clearly established that the E.S.R. is not dependent upon any one factor, but is the result of a complex interplay among various influences, the most important being plasma proteins, chiefly fibrinogen and globulins. It is also established that fibrinogen exerts a strong accelerating effect on the E.S.R. and that there may be a linear correlation between the E.S.R. and the plasma fibrinogen concentration, although there may be a great increase in the E.S.R. without a significant increase in the fibrinogen (Gilligan and Ernstene, 1934; Ham and Curtis, 1938; Nichols, 1942; Meyers et al., 1953). Morrison (1946) suggested that qualitative changes in the fibrinogen fractions were the basis of rapid erythrocyte sedimentation. McFarlane and O'brien (1946) stated that the most active factors increasing the E.S.R. were fibrinogen and euglobulin while those lowering the E.S.R. were albumin and nucleoprotein. Malmroos and Blix (1946) stated that although fibrinogen was an important factor, a rise of alpha ${ }_{2}$, beta or gamma globulins might be associated with a raised E.S.R. Linko et al. (1955) found that in patients with myocardial infarction increased E.S.R. values were primarily determined by increase in fibrinogen and alpha $a_{2}$ globulin and decrease in albumin and alpha ${ }_{1}$ globulin and that beta and gamma globulins did not contribute to changes in the E.S.R. In patients with heart failure, McGinnis et al. (1953) considered it unlikely that alteration in plasma fibrinogen was a contributory factor in elevation of the E.S.R. after compensation. Parry (1961) found no relationship between changes in the E.S.R. after compensation and the concentration of plasma fibrinogen or serum globulins. In the present study it was clear that changes in the E.S.R. after compensation could not be correlated to changes in total proteins, albumin, or globulin fractions. The data, however, strongly favour the assumption that increase of fibrinogen values is the most important factor in the rise of E.S.R. after compensation. The finding that fibrinogen values became abnormally elevated from initial normal values in 10 cases and increased by more than 100 mg. in 13 is very significant. It warrants the assumption that during congestive heart failure the fibrinogen level decreases and that, with establishment of compensation, it returns to the original level; it also suggests that the deficiency in the fibrinogen is responsible for the retardation of the E.S.R. during congestive failure.

The question arises as to what is the mechanism of decrease of fibrinogen level during heart failure. There are two possibilities. First, the increase in the circulating blood volume which occurs in congestive failure may lead to hæmodilution, and consequently, decrease in the concentration of fibrinogen. This does not seem to be the likely cause because, in that case, along with elevation of the E.S.R. and the fibrinogen, the protein fractions should have also increased after compensation. This was, however, not found and the changes in protein fractions were inconstant. Secondly, chronic passive congestion of the liver may lead to diminished production of the fibrinogen by the liver. It is generally agreed that congestive heart failure is usually associated with impairment of liver function which has a tendency to parallelism with the severity of heart failure (Altschule, 1938; Bernstein et al., 1942; Felder et al., 1950; Evans et al., 1952). Parry (1961) noted some relationship between the E.S.R. changes and the severity of heart failure which they stated might be fortuitous. In our series it is noted that the E.S.R. values were $20 \mathrm{~mm}$. or less in all 18 patients in whom either the venous pressure was increased to more than $18 \mathrm{~cm}$. or in whom the arm to lung and the arm to tongue circulation times were prolonged to more than 10 and 20 seconds, respectively. This pointed to some relationship between the low E.S.R. values and the severity of heart failure although it was not a parallel relationship. Liver function, as judged by increased serum bilirubin, decreased cholesterol, and abnormal thymol turbidity and flocculation tests, was abnormal in the majority of our patients. It is, therefore, most likely that impairment of liver function as a result of chronic passive congestion decreases fibrinogen production by the liver. Such changes in fibrinogen 
can be definitely established if determinations are obtained before the onset of failure and after decompensation.

\section{SUMMARY}

With a view to determining the cause of retardation of E.S.R. in congestive heart failure, the E.S.R. and some of the factors known to influence it have been studied in 35 patients during failure and after establishment of compensation. These included liver function tests, total serum proteins and electrophoretic fraction of serum proteins, and plasma fibrinogen.

On admission impaired liver function was found in a majority of the patients. Decreased values were found for total serum proteins, serum albumin, and alpha ${ }_{1}$ globulins, while increased values were obtained in the case of alpha 2 , beta, and gamma globulins. After compensation these abnormalities of protein concentration persisted in almost all of the cases. Alterations in their values showed no relation to changes in the E.S.R. after compensation.

Plasma fibrinogen values increased significantly in 23 of 28 patients in whom there was significant elevation of E.S.R. after compensation; in 13 cases the values increased by more than $100 \mathrm{mg}$. per cent. The data strongly suggest that during heart failure the fibrinogen level is decreased owing to impairment of liver function with consequent retardation of E.S.R.; they also indicate that the increase of fibrinogen concentration is the most important factor in the elevation of the E.S.R. after compensation.

Dr. L. R. Sarin, Superintendent, S. M. S. Hospital, kindly permitted the publication of this report.

\section{REFERENCES}

Altshule, M. D. (1938). Medicine, 17, 75.

Bernstein, M., Le Winn, E. B., and Simkins, S. (1942). J. Lab. clin. Med., 28, 1.

Evans, J. M., Zimmerman, H. J., Wilmer, J. G., Thomas, L. J., and Ethridge, C. B. (1952). Amer. J. Med., 13, 704.

Felder, L., Mund, A., and Parker, J. G. (1950). Circulation, 2, 286.

Flynn, F. V., and Mayo, P. de. (1951). Lancet, 2, 235.

Gilligan, D. R., and Ernstene, A. C. (1934). Amer. J. med. Sci., 187, 552.

Ham, T. H., and Curtis, F. C. (1938). Medicine, 17, 413 and 447.

Hammond, J. D. S., and Ross, R. S. (1960). Clin. Sci., 19, 119.

Haslewood, G. A. D., and King, E. J. (1937). Biochem. J., 31, 920. Cited by King E. J. (1951). Microanalysis in Medical Biochemistry. J. \& A. Churchill Ltd., London, p. 37.

Herrmann, G. R. (1946). Ann. intern. Med., 24, 893.

Linko, E., Waris, E., and Alikoski, H. A. (1955). Acta med. scand., 153, 389.

Malmroos, H., and Blix, G. (1946). Acta med. scand. supp., 170, 280.

McFarlane, R. G., and O'Brien, J. R. (1946). Practitioner, 157, 1.

McGinnis, A. E., Lansche, W. E., Glaser, R. J., and Loeb, L. H. (1953). Amer. J. med. Sci., $225,599$.

McLagan, N. F. (1947). Brit. med. J., 2, 197.

Meyers, A. J., Trevorrow, V., Washburn, A. H., and Mugrage, E. R. (1953). Blood, 3, 893.

Moore, S. S., and Van Slyke, D. D. (1930). J. clin. Invest., 8, 337.

Morrison, I. R. (1946). Amer. J. med. Sci., 211, 325.

Nichols, R. E. (1942). J. Lab. clin. Med., 27, 1317.

Parry, E. H. O. (1961). Acta med. scand., 169, 79.

Quick, A. J. (1942). The Hemorrhagic Diseases and the Physiology of Hemostasis. C. C. Thomas, Springfield, Illinois, Cited by Stefanini, M. and Dameshek, W. (1955). The Hemorrhagic Disorders. Grune \& Stratton, New York, p. 308.

Sanghvi, L. M. (1960). Postgrad. med. J., 36, 620.

Sundermann, F. W., Jr., and Sundermann, F. W. (1957). Amer. J. clin. Path., $27,125$.

Van Slyke, D. D., and Cullen, G. E. (1917). J. biol. Chem., 30, 289.

Wintrobe, M. M. (1956). Clinical Hematology. Lea and Febiger, Philadelphia, p. 367. 